Relations industrielles

Industrial Relations

\title{
The Fifth A.P.I. Convention
}

\section{Gaston Cholette}

Volume 5, numéro 3, décembre 1949

URI : https://id.erudit.org/iderudit/1023301ar

DOI : https://doi.org/10.7202/1023301ar

Aller au sommaire du numéro

Éditeur(s)

Département des relations industrielles de l’Université Laval

ISSN

0034-379X (imprimé)

1703-8138 (numérique)

Découvrir la revue

Citer cet article

Cholette, G. (1949). The Fifth A.P.I. Convention. Relations industrielles /

Industrial Relations, 5(3), 26-27. https://doi.org/10.7202/1023301ar

Tous droits réservés @ C Département des relations industrielles de l’Université Laval, 1949
Ce document est protégé par la loi sur le droit d'auteur. L'utilisation des services d'Érudit (y compris la reproduction) est assujettie à sa politique d'utilisation que vous pouvez consulter en ligne.

https://apropos.erudit.org/fr/usagers/politique-dutilisation/ 
of the proceedings paid tribute to the vision and the courage of Father Dion for having organized and directed this Roundtable.

Future conferences should be very successful. The pattern has been set, a mood has been created and an objective has been clearly defined. To a stranger from south of the border, it appeared that on those two November days the Kent House harbored too many men of intelligence and good will for anything but a most successful future.

\section{THE FIFTH A. P. I. CONVENTION \\ Gaston Cholette}

The Association professionnelle des industriels held a brilliant convention in Quebec City the fourteenth and fifteenth of November. The setting was excellent and the prestige and worth of the speakers added to the conspicuous success of the meetings.

The organizers had thought it opportune to single out the May seventh address of His Holiness, Pius XII for the consideration of the members with the following title as the central theme «The Employer and his Enterprise ».

The first address, bearing on employeremployee co-operation, was delivered by Mr. Gilbert Ayers, of the Ayers Co. Ltd., of Lachute. In the course of his exposition and the discussion which followed, the importance of the advanced social security measures of private initiative with their relatively low cost and their favourable repercussions on the workers especially at times of wage increase demands, was stressed.

At lunch time a substantial bit of philosophy on the rights of ownership was presented by a well-known university professor, Father Louis Lachance, o.p. The speaker brought to light the traditional base of ownership rights in general, the elements justifying private ownership and, above all, the social function of private ownership. The universal satisfaction of human needs is one of the primary requirements of natural law he said, and private ownership is good only in the measure that it constitutes an efficacious means of fulfilling this role. Afterwards, the undersigned asked Father Lachance if certain parts of his speech could be interpreted as expressing a divergence of opinion with some conclusions of the pamphlet of the «Sacerdotal Commission of Social Studies » on «The Sharing of Workers in the Life of the Enterprise ». The learned Dominicain replied that he had read this publication with care and that nothing in his own speech contradicted the thought of the Sacerdotal Commission.

Monday afternoon was marked by two exceedingly interesting addresses - one on industrial organization, the other on reforms of structure in the enterprise. The first was given by Monsieur Marcel Clément and the second by Monsieur François-Albert Angers. The most important conclusion arising from them was the joint proposal of the two speakers to the A.P.I. that they form industrial groups with the mission of instituting a regular, systematic and organic co-operation with the corresponding branches of the workers' syndicates with a view of realizing as efficiently as possible the employer-employee collaboration asked for in the encyclicals and other pontifical texts. This important exhortation, seen in the perspective of the Pope's address of May seventh and in its relation with the later speeches of Monsieur Vittorio Vaccari and Monseigneur Roy, constitutes one of the best resolutions which could have been formulated on this occasion by an employers' association of Catholic inspiration.

The first day came to a close with the address of Monsieur Vittorio Vaccari, general-secretary of the «Association des employeurs catholiques de Belgique», and the speech of His Excellence Monseigneur Maurice Roy, Roman Catholic Archbishop of Quebec. Monsieur Vaccari had been invited to speak of the social directives of Pius XII and particularly to interprete his discourse of May seventh to employers. Here are some important extracts from his text. "One should interprete it (this discourse of Pius XII) in the framework of the social directives which, beginning with Rerum Novarum, the Papacy has never ceased giving the peoples of the earth... There are some who have incorrectly discovered in this address a change of direction with regard to the principles enunciated in the other documents... And it is necessary to state that in certain circles there are employers who, having given only a superficial and partial examination, have mutilated the organic construction of the speech in such a fashion as to interpret it as an exposition of the natural rights of the employer rather than also and equally an exposition of his obligations. » A little further on 
Monsieur Vaccari states: « Private enterprise seems to be the place where the relations of common responsibility may develop most easily in so much as these are the living product of the free initiative of individuals and their freely-constituted groupings ».

Monseigneur Maurice Roy, Archbishop of Quebec, emphasized two points in particular: employers should themselves take the initiative of social progress and to do this in conformity with the doctrine of the Church, they have as well the duty to be obedient to the directives of the Episcopate which alone is qualified to interpret and judge applications of principle. Monseigneur Roy praised the dynamic role played by employers in economic life.

The second day of the Conference was given over the annual general meeting of the A.P.I.

Finally, an address from Monsieur Maurice Duplessis brought the Conference to an end. The prime-minister made certain declarations on problems such as private enterprise, centralization, strikes, respect for authority, etc.

Here is the text of the resolutions adopted by the A.P.I.:

\section{Strikes}

Whereas the common good requires that order and peace be maintained in society;

Whereas industrial workers cannot be deprived of their right to work except for grave reasons and with the consent of the majority;

The congress of the Association professionnelle des industriels asks, at the instance of the governments of the province of Quebec and of Canada, that the necessary legislation be adopted to provide, in taking account of the principles of a just strike, that no strike can be declared or effectuated unless a majority of the workers of the firm concerned have freely voted by secret ballot, under the surveillance of a representative of the State, and the motive or motives for the strike have been explained clearly and in detail to the workers concerned.

\section{Employer-employee collaboration}

Considering that the social doctrine of the Church asks for collaboration between employers and employees;

Considering that the interest of employers and employees demands such collaboration;

Considering that one of the principal ends for which the A.P.I. was founded is precisely this collaboration between employers and employees;
Considering that the practical experience of employers demonstrates the precious advantages of this collaboration;

The Association professionnelle des industriels, gathered in congress at Quebec:

a) expresses its complete satisfaction with the work so far accomplished among the members toward employeremployee collaboration;

b) strongly insists that throughout this program of collaboration a true spirit of justice and charity be emphasized;

c) particularly recommends committees of cooperation as an efficient means of realizing and intensifying this collaboration;

d) asks that employers take into consideration the development of the workers' personality to the level of their competence, their responsability and risks.

\section{Social Security}

The Association professionenlle des industriels, gathered in plenary congress:

1. Recommends that the forms of social security which can be carried into effect take account of the normal role which employers, employees, and the State respectively should play in this sphere.

2. Asks of governments and other concerned to proceed with all necessary prudence in order not to undertake anything which could conduce directly or indirectly to collectivism.

\section{Plan of Association}

In view of making concrete the bonds of natural sympathy which exist between Italian and Canadian employers, and in order to strengthen the relations established between the U.C.I.D. and the A.P.I., upon the occasion of the congress of the U.N.I.A.P.A.C. at Rome, it is proposed and resolved that there be founded an ItaloCanadian employers' association which will have the task of developing social relations, of furnishing information - industrial and otherwise - and of establishing a closer collaboration between the two countries.

The council will be composer of five Canadian directors and five Italian directors and a secretary.

\section{The U.N.I.A.P.A.C.}

The Association professionnelle des industriels, gathered in plenary congress at Quebec, reiterates its entire union with the Union internationale des associations patronales catholiques and repeats its desire of collaborating with the other christian employers of all countries toward the realization of Christian social doctrine.

It addresses its felicitations to the Association des patrons catholiques d'Italie for the brilliant success of its congress at Rome last May.

It adheres entirely to the directives of the Holy Father in his allocution to the employers of all countries which is considered the charter of christian employers. 